\title{
Production of long helical capsid of Nipah virus by Pichia pastoris.
}

\begin{abstract}
The nucleocapsid $(\mathrm{N})$ protein of Nipah virus $(\mathrm{NiV})$ produced in a recombinant host can replace the use of inactivated virus as a diagnostic reagent because it is safer and affordable. The aim of this study was to express the $\mathrm{N}$ protein in Pichia pastoris. The $\mathrm{N}$ gene of $\mathrm{NiV}$ was cloned into the yeast expression vector, pPICZ B and expressed in P. pastoris. The recombinant $\mathrm{N}$ protein of $\mathrm{NiV}$ was purified using sucrose density gradient ultracentrifugation and was confirmed with Western blotting using rabbit anti-N antibody. The P. pastoris expressed $\mathrm{N}$ protein self-assembled into helical structures as large as $1.5 \mu \mathrm{m}$ as shown in an electron micrograph. ELISA analysis performed with the swine sera obtained during the viral outbreak proved that the recombinant $\mathrm{N}$ protein to be highly antigenic. The $\mathrm{NiV} \mathrm{N}$ protein produced in $\mathrm{P}$. pastoris serves as an alternative to the recombinant $\mathrm{N}$ protein produced in Escherichia coli.
\end{abstract}

Keyword: Paramyxovirus; Nipah virus; Nucleocapsid protein; Helical structure; Pichia pastoris. 